\title{
Numerical Investigation \\ of Influence Thermal Preparation Coal \\ on Nitric Oxides Formation \\ in Combustion Process
}

\author{
Nelya S. Chernetskaya ${ }^{a}$, \\ Mikhail Yu. Chernetskiy ${ }^{\mathrm{a}, \mathrm{b} *}$ and Alexander A. Dekterev ${ }^{\mathrm{a}, \mathrm{b}}$ \\ ${ }^{a}$ Siberian Federal University \\ 79 Svobodny, Krasnoyarsk, 660041, Russia \\ ${ }^{b}$ Kutateladze Institute of Thermophysics, SB RAS, \\ 1 Lavrentev, Novosibirsk, 630090, Russia
}

Received 05.12.2013, received in revised form 21.01.2013, accepted 02.02.2014

Emissions of nitrogen oxides from coal combustion are a major environmental problem because they have been shown to contribute to the formation of acid rain and photochemical smog. Coal thermalpreparation before furnace delivery is effective method to reduce NOx emissions, shown by experiments in small-scale facilities [1]. This paper presents the mathematical model of burning thermal preparation coal. Validation of the model was carried out on laboratoryscale plant of All-Russia thermal engineering institute. Modeling of low-emissive burner with preliminary heating coal dust is made for the purpose of search of burner optimal constructions which provides low concentration of nitric oxides in the boiler. For modeling are used in-house CFD code «SigmaFlow» [2].

Keywords: NOx, boiler, thermalpreparation coal, CFD.

\section{Introduction}

Existing problems of using coal in the boiler units to a large extent can be overcome by the burning of coal dust to expose to heat treatment directly at the plant. Heat treatment of coal samples leads to significant changes in the composition and properties of solid residue, which is to reduce the yield of volatile substances and oxygen, to increase the caloric content of residual volatile matter and calorific solid residues. Good flammability of products of heat treatment, high caloric content and their reactivity, environmental cleanliness provide ample opportunities for use in thermal power plants the pre-thermal preparation of coal before burning.

In 1980-1983 at the experimental facility of the institute, detailed studies of the influence of preliminary heat of fuel preparation on the nitrogen oxides formation were carried out. Coal dust, with varying degrees of metamorphism: berezovskiy lignite coal ( $\mathrm{V}^{\mathrm{daf}}=44.7 \%, \mathrm{~N}^{\mathrm{daf}}=0.8 \%$ ), ekibustuzskiy

(C) Siberian Federal University. All rights reserved

* Corresponding author E-mail address: micch@yandex.ru 
bituminous coal ( $\left.\mathrm{V}^{\text {daf }}=31.2 \%, \mathrm{~N}^{\text {daf }}=1.5 \%\right)$ and kuznetskiy lean coal $\left(\mathrm{V}^{\text {daf }}=13.5 \%, \mathrm{~N}^{\text {daf }}=2.2 \%\right)$ were used. The studies were conducted in a wide range of temperature (until $820^{\circ} \mathrm{C}$ ) and heating rate of air into the burner $(\alpha=0.92 \ldots 1.25)$. It was found that preheating of highly concentrated dust suspension in a gaseous medium by a factor of the oxygen $\alpha \leq 0.05$ until $600 \ldots 820^{\circ} \mathrm{C}$ outlet of fuel nitrogen oxides can be reduced by 2-5 times. These studies were confirmed on the demonstration plant of heat power $1.12 \mathrm{MW}$ at combustion kuznetskiy low-caking coal. When heated dust to $585{ }^{\circ} \mathrm{C}$ decrease emissions of nitrogen oxides is almost 2.5 times compared with conventional regime without heating the dust reached. It is established that the heating of pulverized coal considerably improves conditions: temperature increase in the axial zone of reverse flow at the initial part of a torch and in the core burning is reduced almost by half the distance from the mouth of the burner to the zone of maximum temperatures.

The data obtained were used to develop a full-scale pulverized-coal burner design with prethermal treatment of fuel. In 1983-1984 this burner heat output of $60 \mathrm{MW}$ has been implemented and tested on an industrial boiler TPP-210A. Further tests were carried out on other boiler units using the system for heating fuel in burners. All tests confirmed the feasibility of using these burners. In all cases it was possible to reduce nitrogen oxide emissions from 1200 and 1800 to 500 and $700 \mathrm{mg} / \mathrm{m}^{3}$ respectively at combustion of kuznetskiy lean and low-caking coals [3].

To further implement this technology on the boilers of various designs at burning coals of various grades is necessary to conduct additional studies, including by means of numerical simulations. In this paper the mathematical model and some results of thermal preparation coal combustion calculation are examined.

\section{Mathematical model}

The model of non-isothermal incompressible multi-component gas was assumed as a model of flow in combustion chamber. The gas flow in the studied problem is considered as established, thus all equations are written in the steady-state form. It is assumed that combustion gases consist of $\mathrm{N}_{2}, \mathrm{O}_{2}$, $\mathrm{CO}_{2}, \mathrm{H}_{2} \mathrm{O}$ and complex of volatiles VOL. The model includes the following equations:

equation of continuity

$$
\frac{\partial \rho}{\partial t}+\nabla(\rho \mathbf{v})=0
$$

equation of momentum balance

$$
\begin{aligned}
\frac{\partial \rho \mathbf{v}}{\partial t} & +\nabla(\rho \mathbf{v} \cdot \mathbf{v})=-\nabla p+\nabla\left(\boldsymbol{\tau}^{m}+\boldsymbol{\tau}^{t}\right) \\
& +\left(\rho-\rho_{\infty}\right) \mathbf{g}
\end{aligned}
$$

where the viscous stress tensor is

$$
\tau_{i j}^{m}=\mu\left[\left(\frac{\partial u_{i}}{\partial x_{j}}+\frac{\partial u_{j}}{\partial x_{i}}\right)-\frac{2}{3} \delta_{i j} \frac{\partial u_{k}}{\partial x_{k}}\right],
$$

$\tau^{\mathrm{t}}$ is the Reynolds stress tensor;

equation of $\mathrm{i}$-th component concentration (mass fraction) transfer 


$$
\frac{\partial \rho f_{i}}{\partial t}+\nabla\left(\rho \mathbf{v} \cdot f_{i}\right)=\nabla\left(\left(D_{i}+\frac{\mu_{t}}{S c_{i}}\right) \cdot \nabla f_{i}\right)+S_{i}
$$

where $D$ is the molecular diffusion constant, $S c$ - turbulent Schmidt number, $S$ - source term describing reactions;

equation of energy transfer

$$
\begin{aligned}
\frac{\partial \rho h}{\partial t} & +\nabla(\rho \mathbf{v} \cdot h)=\nabla\left(\left(\lambda+\frac{c_{P} \mu_{t}}{P r_{t}}\right) \cdot \nabla T\right) \\
& +S_{c h}+S_{R},
\end{aligned}
$$

$S_{c h}, S_{R}$ are source terms describing, correspondingly, energy effect of reactions and radiation heat transfer.

The modified high-Reynolds k- $\varepsilon$ model of turbulence (Chen k- $\varepsilon$ model) is used to describe the turbulent characteristics of flow. The equations determining the kinetic energy of turbulence and its dissipation rate have a form (Chen and Kim, 1987):

$$
\begin{gathered}
\frac{\partial \rho k}{\partial t}+\nabla(\rho \mathbf{v} \cdot k)=\nabla\left(\left(\mu+\frac{\mu_{t}}{\sigma_{k}}\right) \cdot \nabla k\right)+G-\rho \varepsilon \\
\frac{\partial \rho \varepsilon}{\partial t}+\nabla(\rho \mathbf{v} \cdot \varepsilon)=\nabla\left(\left(\mu+\frac{\mu_{t}}{\sigma_{\varepsilon}}\right) \cdot \nabla \varepsilon\right) \\
+C_{1} \frac{\varepsilon}{k} G-C_{2} \rho \frac{\varepsilon^{2}}{k}+C_{3} \frac{G^{2}}{\rho k}
\end{gathered}
$$

where $\mathrm{G}$ is the rate of turbulence generation:

$$
G=\tau_{i j}^{t} \frac{\partial u_{i}}{\partial x_{j}}
$$

turbulent viscosity is determined as

$$
\mu_{t}=C_{\mu} \rho \frac{k^{2}}{\varepsilon}
$$

Reynolds stress tensor has a form

$$
\tau_{i j}^{t}=\mu_{t}\left[\left(\frac{\partial u_{i}}{\partial x_{j}}+\frac{\partial u_{j}}{\partial x_{i}}\right)-\frac{2}{3} \delta_{i j} \rho k\right] .
$$

The empirical constants $\mathrm{C} \mu=0.09, \sigma_{\mathrm{k}}=0.8, \sigma_{\varepsilon}=1.15, \mathrm{C}_{1}=1.15, \mathrm{C}_{2}=1.9, \mathrm{C}_{3}=0.25$ are given in the work (Chen and Kim, 1987). These constants are approved for a wide class of isothermal flows. The form of $\mathrm{k}-\varepsilon$ model is adapted for fully developed turbulent flows. In the near-wall region wall function are used to save computational resources.

Temperature of mixture $\mathrm{T}$ in each point of flow field is found using the known local values of enthalpy and mixture components content:

$$
h=\sum_{m=1}^{N} h_{m}(T) f_{m},
$$


where the dependencies of component enthalpy on temperature $h_{m}(T)$ is described by polynomials of 5th degree.

The radiation is the dominant heat transfer mechanism. The modeling of radiant energy transfer is conducted basing on the P1 approximation of spherical harmonics for a grey medium (Siegel and Howell, 1992). The advantage of this method is easiness of its matching with methods of aerodynamics and heat transfer calculation realized in curvilinear meshes. The absorption coefficients were calculated using the weighted-sum-of-gray-gases model.

Calculation of volatile fuel components combustion is based on the use of global irreversible reactions between fuel and oxidant. To describe the reaction in turbulent flows with large mixing time used a hybrid model using the kinetic model and the eddy break up model to determine the reaction rate. According to this model as the resultant velocity is chosen the lowest from rates:

$$
R_{i}=-M I N\left(\left|R_{i, K I N}\right|,\left|R_{i, E B U}\right|\right)
$$

Coal Dust Combustion. The Lagrange method was used in the present work to model of coal dust motion. During the modeling, the main forces acting on a particle were the force of phases interaction (aerodynamic resistance force) and gravity force. As the coal particles moves, it is heated up and it undergoes a number of process: extraction of residual moisture and volatile components, combustion of volatile components and char. When the coal particle advances in the furnace, the reaction processes of vaporization, coal pyrolysis and char combustion are considered. The coal particle consists of four components: water, volatiles, carbon and ash. Vaporization of moisture from the coal particle is described by the diffusion-limited model. Coal pyrolysis is modelled by a simple, one-step mechanism and the volatile composition is assumed to be constant. The reaction rate of coal pyrolysis is taken from experimental data.

Char combustion is controlled by the chemical surface reaction and the oxygen diffusion to the particle. This model includes the factor $\eta$ which describes the transition between the char combustion regime limited by the rate of oxygen diffusion and the regime is sufficiently limited by the chemical reaction rate. Char particles are considered to burn at constant density and variable size.

The diameter change of a particle follows:

$$
\begin{aligned}
& \frac{d \delta}{d \tau}=\frac{2}{\rho_{K}} * K_{S}^{c} \\
& K_{S}^{C}=\beta C_{O 2}\left(273 / T_{g}\right) * \alpha_{K} \\
& \alpha_{K}=\frac{1}{\frac{1}{\alpha_{k . k i n}}+\frac{1}{\alpha_{k . d i f f}}} \text { if } \alpha_{k . k i n}<\eta \alpha_{k . d i f f} \\
& \alpha_{K}=\alpha_{k . d i f f} \text { if } \alpha_{k . k i n}>\eta \alpha_{k . d i f f} \\
& \alpha_{k . d i f f}=\frac{N u_{D} D}{\delta} \\
& N u_{D}=2+0.22 P e^{0.66} \\
& \alpha_{k . k i n .}=K_{K} e^{-E_{K} / R T}
\end{aligned}
$$


$\rho_{\mathrm{k}}$ is the density of the char particle $\left(\mathrm{kg} \mathrm{m}^{-3}\right) ; \mathrm{K}_{\mathrm{S}}{ }^{\mathrm{C}}$ is the char combustion rate $\left(\mathrm{kg} \mathrm{m}^{-2 *} \mathrm{~s}^{-1}\right) ; \mathrm{Nu}_{\mathrm{D}}$ is the diffusion Nusselt number; $\mathrm{D}$ is the bulk molecular diffusion coefficient $\left(\mathrm{m}^{2} / \mathrm{s}\right) ; \alpha_{\mathrm{k}}$, kin is the reaction-rate coefficient for a chemical reaction $\left(\mathrm{ms}^{-1}\right), \alpha_{\mathrm{k}, \mathrm{diff}}$ is the reaction-rate coefficient for diffusion $\left(\mathrm{ms}^{-1}\right)$.

The instantaneous burning rate of an individual particle is determined from temperature, velocity, and size information by solving the energy balance for the particle, assuming a spherical, homogeneous, reacting particle surrounded by a chemically frozen boundary layer (i.e., single-film model). Heat losses from convection and radiation are considered, as well as the effects Stefan flow:

$$
\frac{m_{p} C_{p}}{4 \pi r_{p}^{2}} \frac{d T_{p}}{d t}=\varepsilon \sigma\left(T_{\text {rad }}^{4}-T_{p}^{4}\right)+\alpha_{\text {conv }}\left(T-T_{p}\right)+\frac{Q H}{4 \pi r_{p}^{2}}
$$

$\alpha_{\text {conv }}$ is the convection heat transfer coefficient:

$$
\alpha_{\text {conv }}=\frac{N u \lambda}{2 r_{p}}
$$

The correction to the heat-transfer equation due to Stefan flow is provided modification of Nusselt number:

$$
N u=2+\frac{P e}{2}-\frac{37}{960} P e^{2}-\frac{P e \overline{P e}}{4}-\frac{\overline{P e}}{2}
$$

where $P e$ is a Peclet number, $\bar{P} e$ is a modified version of the Peclet number (i.e., the ratio of the convective velocity of the net mass leaving the particle surface to the diffusive velocity of heat leaving the surface).

When char burn, heat losses from convection is much larger than that is predicted for not burning particles. In the model is used correlation coefficient $\mathrm{K}_{\text {comb }}$ :

$$
\begin{aligned}
& \alpha_{c o n v}^{c o m b}=\alpha_{c o n v} K_{c o m b} \\
& K_{c o m b}=145 e^{-\frac{5000}{T_{g}}}
\end{aligned}
$$

$\alpha_{c o n v}^{c o m b}, \alpha_{c o n v}$ - are convective heat transfer coefficients for burning and not burning coal particle respectively. Present model of coal particle combustion was validated in [4].

The influence of particles on the averaged gas motion, the gas components concentration and enthalpy was taken into account on the base of PSI-cell method proposed by Crow (Crow et al., 1977).

NOx Formation. In the process of NOx formation simulation three mechanisms are taken into account: formation of thermal NOx according Zeldovich's model (Zeldovich, 1946), formation of prompt NOx according the Fenimore's model (Fenimore, 1979) and formation of fuel NOx (Magel et al., 1996). Additional equations for NO and intermediate hydrogen cyanide $\mathrm{HCN}$ transfer are introduced:

$$
\begin{gathered}
\frac{\partial \rho f_{N O}}{\partial t}+\nabla\left(\rho \mathbf{v} f_{N O}\right)=\nabla\left(D \nabla f_{N O}\right)+S_{N O} \\
\frac{\partial \rho f_{H C N}}{\partial t}+\nabla\left(\rho \mathbf{v} f_{H C N}\right)=\nabla\left(D \nabla f_{H C N}\right)+S_{H C N} \\
-87-
\end{gathered}
$$


The source term in the equation of NO transfer describing thermal mechanism (Zeldovich, 1946) may be written as

$$
S_{\text {thermal-NOx }}=M_{N O} \frac{d[N O]}{d t}
$$

where $\mathrm{d}[\mathrm{NO}] / \mathrm{dt}$ is calculated as following:

$$
\frac{d[N O]}{d t}=\frac{2[O]\left(k_{1} k_{2}\left[O_{2}\right]\left[N_{2}\right]-k_{-1} k_{-2}[N O]^{2}\right)}{k_{2}\left[O_{2}\right]+k_{-1}[N O]}
$$

Assuming the partial equilibrium for oxygen atom density [O], we obtain

$$
[O]=36.64 T^{1 / 2}\left[O_{2}\right]^{1 / 2} \exp (-27123 / T)
$$

Reaction rate constants $\left(\mathrm{m}^{3} /(\mathrm{mol} \cdot \mathrm{s})\right)$ are equal

$$
\begin{aligned}
& k_{1}=1.8 \cdot 10^{8} \exp (-38370 / T) \\
& k_{-1}=3.8 \cdot 10^{7} \exp (-425 / T) \\
& k_{2}=1.8 \cdot 10^{4} \cdot T \cdot \exp (-4680 / T) \\
& k_{-2}=3.8 \cdot 10^{3} \cdot T \cdot \exp (-20820 / T)
\end{aligned}
$$

The prompt NOx forms in the presence of hydrocarbon radicals which prevail in fuels with high molecular H:C rate. The mechanism of prompt NOx formation was described by Fenimore (1979). Source term in the equation of NO transfer may be written

$$
S_{\text {prompt }-N O x}=M_{N O} \frac{d[N O]}{d t},
$$

$\mathrm{d}[\mathrm{NO}] / \mathrm{dt}$ is calculated according the expression:

$$
\frac{d[N O]}{d t}=k_{p r}\left[O_{2}\right]^{a}\left[N_{2}\right][V O L] \exp \left(-\frac{E_{a}}{R T}\right)
$$

where

$$
k_{p r}=1.2 \cdot 10^{7}(R T / \mathrm{p})^{a+1} \quad E_{a}=60 \mathrm{kcal} \cdot \mathrm{mol}^{-1}
$$

Oxygen reaction order $a$ depends on flame conditions (de Soete, 1975).

The fuel NOx is a result of reaction between oxygen and fuel nitrogen. In the process of coal fuel gasification and char burn there takes place the transformation of nitrogen containing compounds to $\mathrm{NH}_{3}$ (ammonia) and HCN (hydrogen cyanide). Depending on scheme of chemical reactions between these compounds and combustion gases, formation of $\mathrm{NO}$ or $\mathrm{N}_{2}$ takes place.

Modified de Soete model (Magel et al., 1996), consisting of three global reactions, is realized to calculate the fuel NOx :

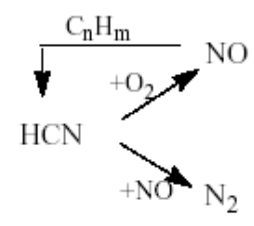




$$
\begin{aligned}
& \frac{d x_{H C N}}{d t}=-3.5 \cdot 10^{10} \exp (-3370 / T) x_{H C N} x_{O_{2}}^{a} \\
& \frac{d x_{H C N}}{d t}=-3 \cdot 10^{12} \exp (-30200 / T) x_{H C N} x_{N O} \\
& \frac{d x_{N O}}{d t}=-2.7 \cdot 10^{6} \exp (-9466 / T) x_{N O} x_{C_{n} H_{m}}
\end{aligned}
$$

Numerical algorithms. Conservation equations for gas phase are written down in a generalized conservation law in a control volume. For the volume finite-difference analog of equation is written down. For calculation of diffusion flow on the face of control volume centrally-difference scheme with second order precision is employed.

At the approximation of convective terms Leonard's scheme is employed that is substantially minimizes the circuit viscosity. For connection velocity and pressure fields SIMPLE-C procedure is employed.

\section{Results}

Validation of the model was carried out on laboratory-scale plant of All-Russia thermal engineering institute. This plant consists of dust preheater in which coal is heated until specific temperature, burner consisting of two coaxial cylinder and combustor. Coal-gas mixture from a preheater moves on the internal flow path, air- on to the external. Original fuel compound is shown in Table 1. Coal and gas compound after preheater are shown in Table 1, 2. Experiments and numerical calculations are carried out with two coal sorts used: brown and black lean coals. The stationary plant is shown in Fig. 1.

The calculation results for black coal are shown in Fig.2, 3. Fig. 3 shows concentration NOx along the furnace. One can see satisfactory agreement with experimental data at volatile nitrogen to total nitrogen ratio equal to one. In Fig. 4, 5 the comparison of calculated and experiment results for brown

Table 1. Coal composition

\begin{tabular}{|l|c|c|c|c|c|c|c|c|}
\hline \multicolumn{8}{|c|}{ Black lean Coal } \\
\hline & $\mathrm{W}$ & $\mathrm{A}$ & $\mathrm{C}$ & $\mathrm{H}$ & $\mathrm{O}$ & $\mathrm{S}$ & $\mathrm{N}$ & $\mathrm{V}$ \\
\hline Until & 1.8 & 22.7 & 67.8 & 2.79 & 2.72 & 0.45 & 1.66 & 13 \\
\hline After & 0.3 & 25.1 & 70.77 & 1.12 & 0.67 & 0.45 & 1.49 & 4.4 \\
\hline \multicolumn{8}{|c|}{ Brown coal } \\
\hline Until & 10.4 & 4.84 & 59.5 & 3.81 & 20.34 & 0.34 & 0.76 & 45.7 \\
\hline After & 0.2 & 7.78 & 77.57 & 2.94 & 10.21 & 0.37 & 0.83 & 18 \\
\hline
\end{tabular}

Table 2: Gas composition, $\%$

\begin{tabular}{|l|l|l|c|c|c|c|l|}
\hline $\mathrm{CO}_{2}$ & $\mathrm{CO}$ & $\mathrm{H}_{2}$ & $\mathrm{CH}_{4}$ & $\mathrm{~N}_{2}$ & $\mathrm{O}_{2}$ & NOx & \\
\hline 15.8 & 10.6 & 6.6 & 0.9 & 61.2 & 0.5 & 0,005 & Black lean Coal \\
\hline 26.9 & 18.7 & 5.1 & 1.52 & 44.7 & 0.3 & 0.016 & Brown coal \\
\hline
\end{tabular}




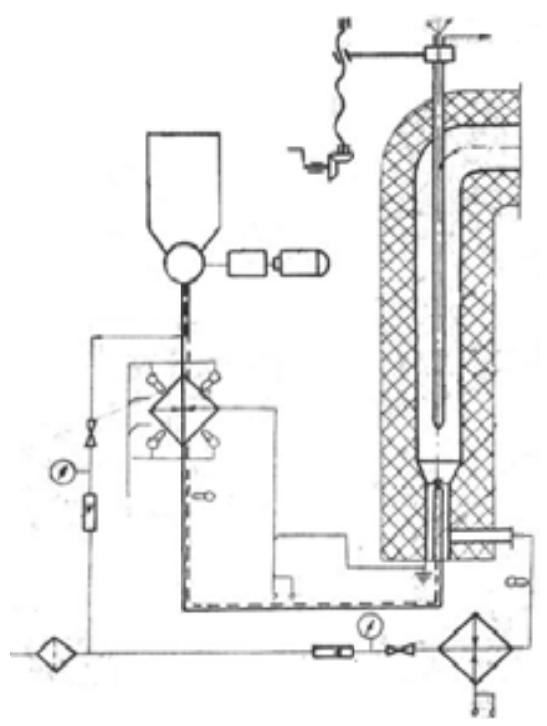

Fig. 1. The stationary plant

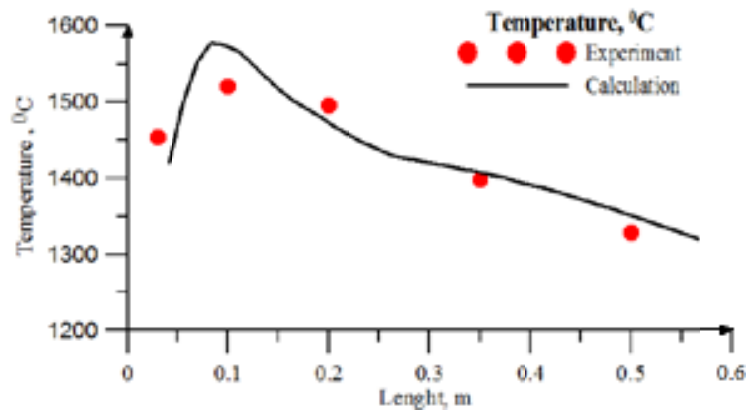

Fig. 2. Temperature $\left({ }^{\circ} \mathrm{C}\right)$ Along the combustor (Black lean coal, $\mathrm{T}_{\mathrm{tp}}=790{ }^{\circ} \mathrm{C}$ )

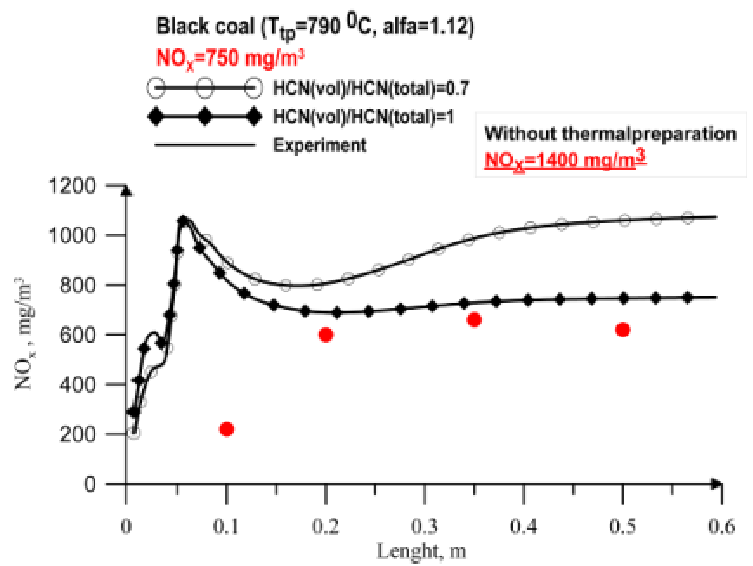

Fig. 3. $\mathrm{NO}_{\mathrm{x}}$ concentration, $\left(\mathrm{mg} / \mathrm{m}^{3}\right)$. Along the combustor 


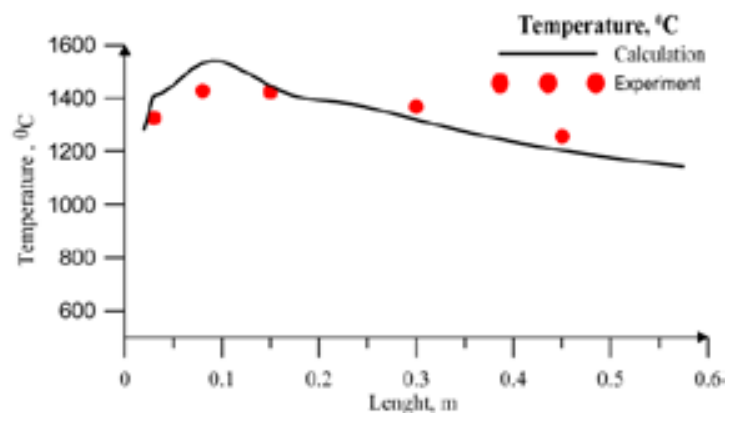

Fig. 4. Temperature $\left({ }^{\circ} \mathrm{C}\right.$ ) along the combustor (Brown coal, $\mathrm{T}_{\mathrm{tp}}=612{ }^{\circ} \mathrm{C}$ )

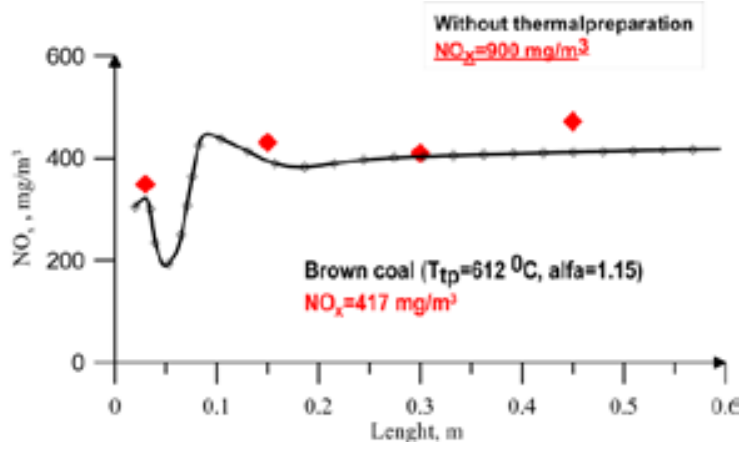

Fig. 5. $\mathrm{NO}_{\mathrm{x}}$ concentration, $\left(\mathrm{mg} / \mathrm{m}^{3}\right)$. Along the combustor

coal. The profiles of the temperature and $\mathrm{NO}_{\mathrm{x}}$ concentration are generally in good agreement with the measurements.

For research heating, combustion coal and also influence of application of thermo-preparation concentration for decrease of nitric oxides the geometrical model of a burner consisting from muffle and furnace extension has been constructed. For research of initial development of a flame, and also, for the purpose of approach to real working conditions of a burner the limited area of combustion space was considered. The sizes of a burner are shown in Fig. 6. Computational grid of burner is presented in Fig. 7.

For calculation there was used black coal the structure of which is represented in Table 3. The analysis of the used coal is given in Table 4.

Fuel with grinding 30 micrometer and a part of primary air at the temperature $25^{\circ} \mathrm{C}$ is tangentially supplyed in to the an input 1 (Fig.6). In the cannel 2 supply of fuel ( $d=90$ micrometer) and air at the temperature $120^{\circ} \mathrm{C}$. Secondary air at the temperature $300^{\circ} \mathrm{C}$ is supplied into the cannel 3. Results of modeling in the form of distribution of temperature and concentration are resulted in Fig.8.

Then, with the aim to study the influence of use of burner with thermo-preparation on decrease of nitric oxides concentration on an exit furnace chamber, modeling of boiler PK-39-IIM (see Fig.10) was carried out. As the initial data for a boiler results of modeling of burner were employed presents above. Comparison was made with a basic variant of boiler without thermo-preparation. The temperature on 

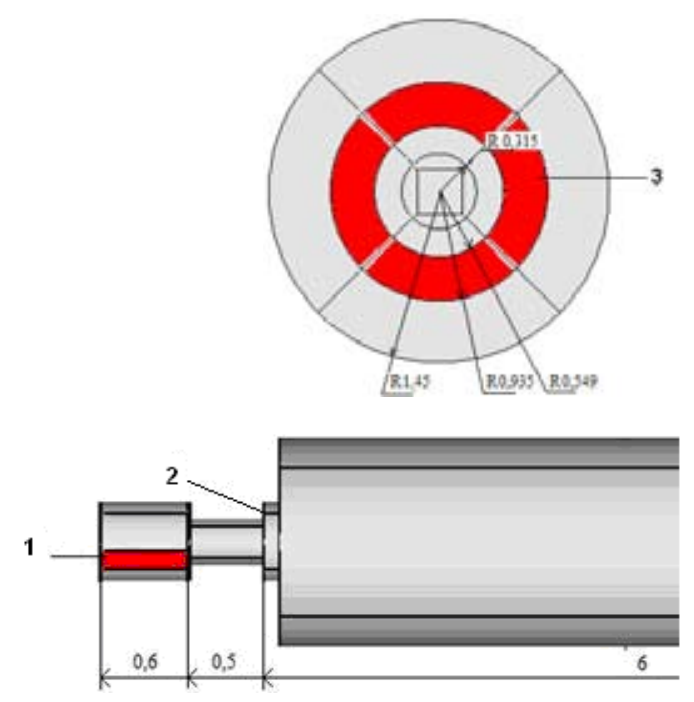

Fig. 6. Geometrical model, m

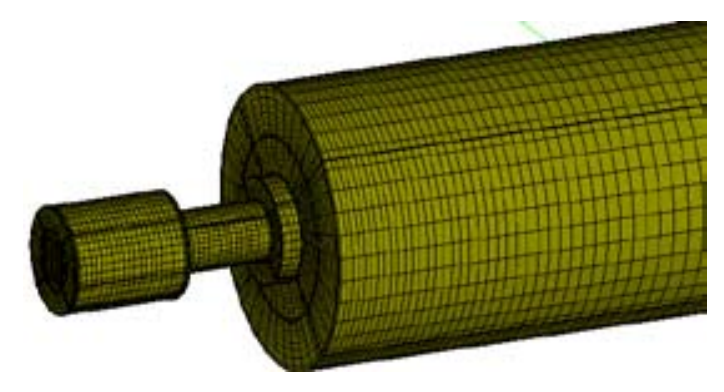

Fig. 7. Computational grid of burner

Table 3. Coal composition

\begin{tabular}{|c|c|}
\hline Characteristic, \% & \\
\hline $\mathrm{C}^{\mathrm{r}}$ & 43 \\
\hline $\mathrm{H}^{\mathrm{r}}$ & 2,7 \\
\hline $\mathrm{O}^{\mathrm{r}}$ & 7 \\
\hline $\mathrm{N}^{\mathrm{r}}$ & 0,8 \\
\hline $\mathrm{S}^{\mathrm{r}}$ & 0,6 \\
\hline $\mathrm{A}^{\mathrm{r}}$ & 39,6 \\
\hline $\mathrm{W}^{\mathrm{r}}$ & 6,3 \\
\hline $\mathrm{V}^{\mathrm{daf}}$ & 31,4 \\
\hline $\begin{array}{l}\mathrm{Q}^{\mathrm{r}}, \\
\mathrm{kcal} / \mathrm{kg}\end{array}$ & 3917 \\
\hline
\end{tabular}

Table 4. Operating conditions of the pulverized-coal combustion burner

\begin{tabular}{|l|c|}
\hline Fuel rate, $\mathrm{kg} / \mathrm{s}$ & 2,08 \\
\hline Total air flow, $\mathrm{m}^{3} / \mathrm{h}$ & 467640 \\
\hline Temperature secondary air, ${ }^{\circ} \mathrm{C}$ & 300 \\
\hline Temperature dust air mixture & 120 \\
\hline Excess air coefficient & 0,812 \\
\hline
\end{tabular}



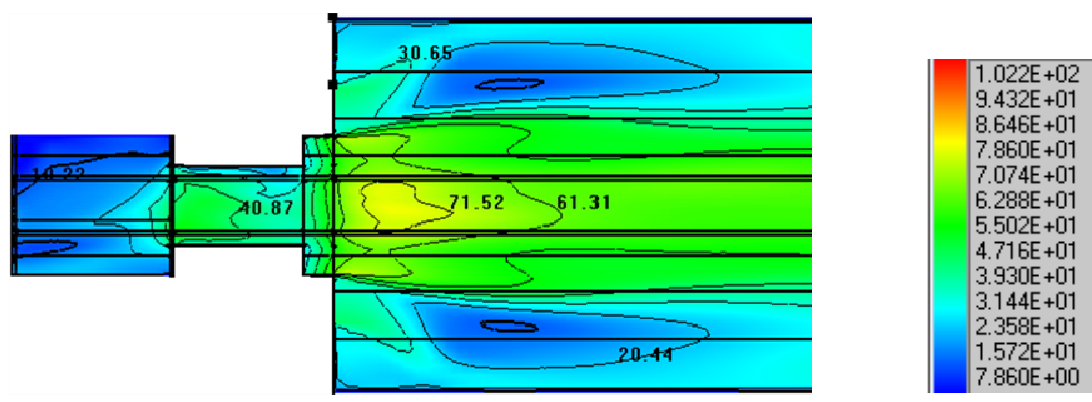

Fig. 8. Module of velocity, $\mathrm{m} / \mathrm{s}$

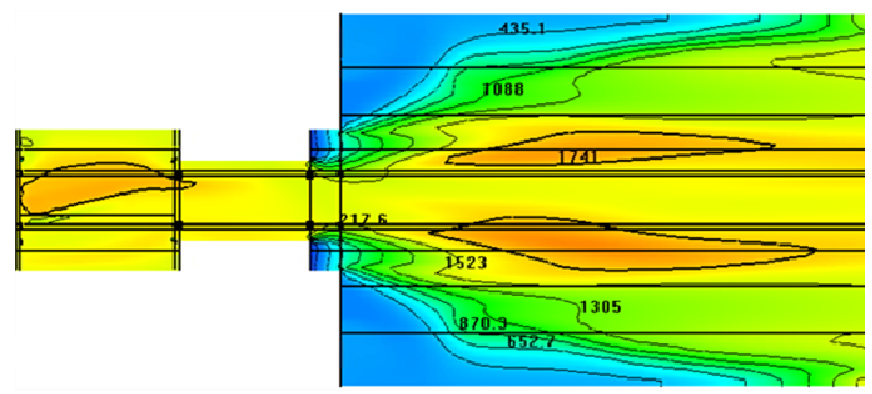

Fig. 9. Temperature distribution, ${ }^{\circ} \mathrm{C}$
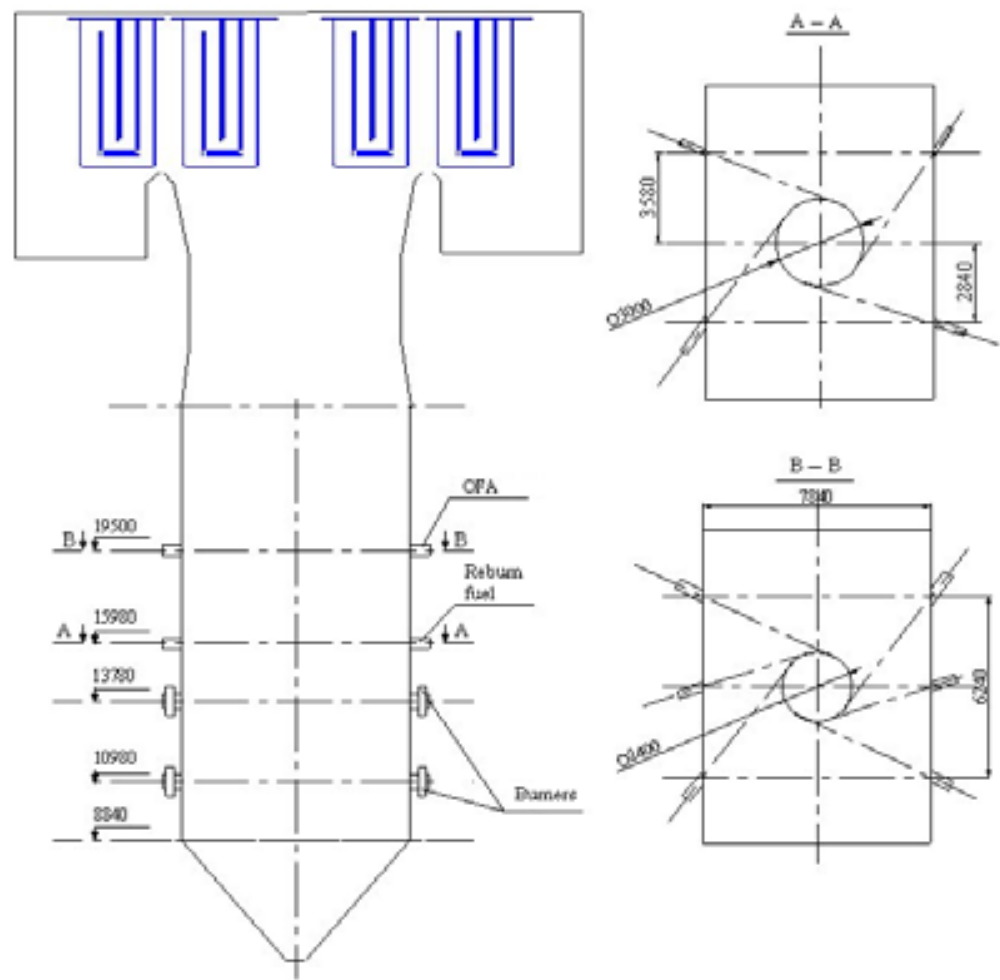

Fig. 10. PK-39-IIM scheme 


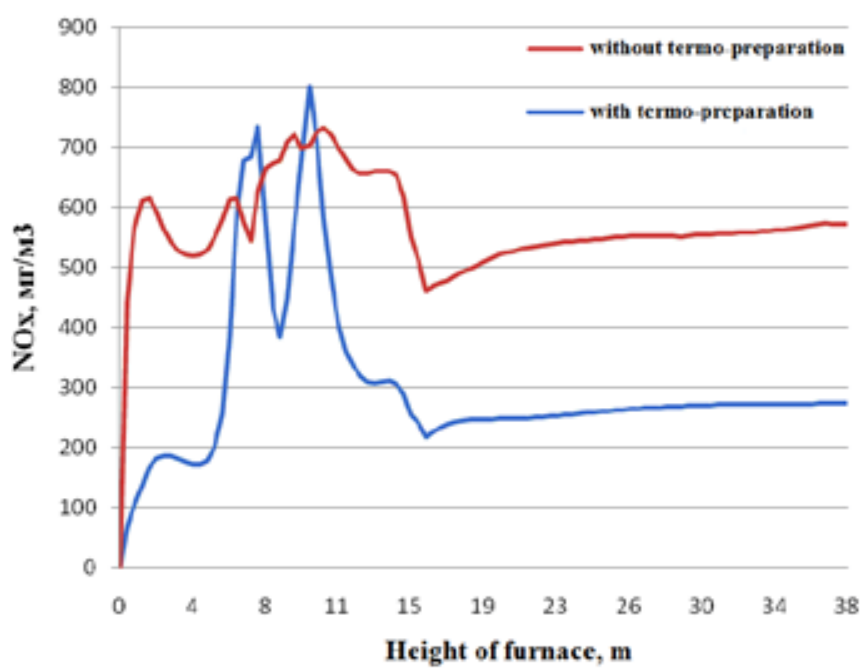

Fig. 11. The nitric oxides concentration upheight of furnace chamber

an exit of furnace was $1167{ }^{\circ} \mathrm{C}$. Unburned carbon $0.17 \%$. NOx concentration on an exit from furnace was $275 \mathrm{mg} / \mathrm{nm}^{3}$ (see Fig.11).

\section{Conclusion}

1. Applicability of the burning thermal preparation coal mathematical model has been validated by comparing its predictions with the experimental data of a laboratory-scale pulverized-coal combustion burner. The results of the calculation show good agreement with the measurements.

2. Numerical research of low emissive burner with step supply of air and preliminary heating coal dust was executed. As a results of calculation optimal sizes of a burner providing heating air-andcoal mixture have been found. The given warming up provides an intensive exit of flying that give the chance to lower nitric oxides concentration on an initial site of a flame.

3. On the basis of the data received at the modeling of low emissive burner modeling of boiler PK39-IIM with thermally prepared fuel was carried out. Application of the given technology of preliminary heating coal dust provides to reduction of nitric oxides concentration in combustion products to level of $275 \mathrm{mg} / \mathrm{nm} 3$.

\section{Acknowledgement}

This work was supported by the Ministry of Education and Science of the Russian Federation. government contract № 14.A18.21.1962 and Russian Foundation for Basic Research (Grant № 14-0801079).

\section{References}

[1] Babiy V.I., Alaverdov P.I., Barbarash V.M. et. al. // Thermal Engineering. 1983. № 9. P. 10-13.

[2] Chernetskii, M. Yu. and Dekterev A.A. // Flame Combustion, Explosion, and Shock Waves. 2011. Vol. 47(3). P. 280-288. 
[3] Babiy V.I., Verboveckiy E. Kh., Artem'ev Iu. P. // Thermal Engineering 2000. № 10. P. 21-28.

[4] Chernetskiy M., Dekterev A., Gavrilov A. // Proc. of ICCHMT09. 2009. P. 409-412.

[5] Crow C.T., Sharma M.P., Stock D.E. // J. Fluids Engg., Trans. of the ASME. 1977. Vol. 99. P. $25-332$.

[6] Zeldovich Y.B., Sadovnikov P.Y., Frank-Kamenetckiy D.A. // 1947 AS USSR. P. 317.

[7] Fenimore C.P. // 17th Symp. (Int.) Comb., The Combustion Institute, Pittsburgh, 1979. P. 661.

[8] De Soete G.G. // In 15th Symp. (Int'll.) on Combustion, The Combustion Institute, 1975. P. 1093.

[9] Magel H.C., Greul U., Schnell U. et. al. // In Proc. Joint Meeting of the Portuguese, British, Spanish and Swedish Section of the Combustion Institute, Madeira, 1996. Vol 1. P. 123-130.

\section{Численное исследование}

\section{Влияния термоподготовки угля}

на образование оксида азота

В процессе горения

Н.С. Чернецкая М.Ю. Чернецкийй,, А.А. Дектерев ${ }^{\mathrm{a}, \tilde{\sigma}}$ ${ }^{a}$ Сибирский федеральный университет, Россия, 660041, Красноярск, пр. Свободный, 79 ${ }^{6}$ Институт теплофизики им. С.С. Кутателадзе СО РАН, Россия, 630090, Новосибирск, пр. Академика Лаврентьева, 1

Выбросы оксидов азота при сжигании углей являются одной из основных экологических проблем, так как они служат причиной возникновения кислотных дождей и смога. Термоподготовка угля перед его сжиганием в топочной камере позволяет значительно снизить образование оксидов азота. В данной статье представлена математическая модель горения угольной пыли, прочедшая предварительную термоподготовку. Тестирование математической модели было выполнено с использованием экспериментальных данных, полученных на огневом стенде ВТИ. Проведены расчеты с иелью оптимизации низкоэмиссионного горелочного устройства с использованием некоммерческого пакета программ вычислительной гидродинамики SigmaFlow.

Ключевые слова: оксиды азота, топочная камера, термоподготовка угля, вычислительная гидродинамика. 